\title{
Spatial Display of Economic Activity in Municipal Districts
}

\author{
Alexander Plyakin \\ Volzhsky Institute of Economics, Pedagogy and Law, \\ Chair of Management \\ Volzhsky, Russia \\ aplyakin@mail.ru
}

\author{
Elena Orekhova \\ Volzhsky Institute of Economics, Pedagogy and Law, \\ Chair of Economics \\ Volzhsky, Russia \\ eorekhova@mail.ru
}

\begin{abstract}
The article touches upon the study results for economic activity factors in municipal districts of Volgograd region. In frames of the conducted research a component model of economic activity was created, a new system of economic activity indicators for municipal development was created, and an ARCGIS-based evaluation approach for spatial variability and diversity of economic activity conditions in municipal districts was suggested. The achieved methodological approaches can be used to create a complex information and analytical system for managing the region's economic activity that will enable to receive data on dynamics of the social and economic processes taking place in the region.
\end{abstract}

Keywords: municipal district, social and economic development, economic activity, spatial approach, geographic information system

\section{INTRODUCTION}

The topicality of studying the economic activity at municipal level is determined by the importance of the role it plays in social and economic sustainable development of regions. Economic activity of market actors is the key factor in integration of ecologic, social and economic components of the sustainable development, as well as their spatial connection in the process of cooperation. Dynamics of economic activity determines the scale and intensiveness of the regional economic system transformation. Thus, search for spatial patterns in development of poles, axes, corridors and zones of economic activity enables to reach a new level of evaluating conditions, resources and factors of sustainable development, which can be characterized as development without destroying the structure of a municipal economy, devaluation of a human and free of any other destructive social and economic processes [1].

The research goal of this work that determines its objectives is execution of the system of economic activity indicators in the geographic information system (GIS) enabling to evaluate spatial aspects and economic activity patterns on the territory of municipal districts of Volgograd region.

Further research stages allowed to tackle the following objectives: to determine methodological instruments for evaluating the economic activity of municipal districts; to form spatial databases and themed digital maps for economic activity in the geographic information system of ARCGIS; to determine spatial patterns of the economic activity conditions at municipal level.

\section{MATERIALS AND Methods (MODEL)}

There are several theoretical approaches to determination of the concept of economic activity today: instrumental (statistical), social-psychological, economic and social, evolutionary and genetic [2], [3], [4], [5], [6]. In their understanding of economic activity the authors were using the latter approach that enabled them to show complex and multifactor nature of economic activity, differentiate its types and conditions, determine acceptable limits and optimal balance of its components. Taking into account the mentioned above, economic activity is an intensity measure of the reproduction process at a respective level characterized by presence of necessary conditions, resources status and cooperation of production factors, as well as the goal and purposes of social and economic development. The need to differentiate economic activity into the types of activities is explained, in particular, by the fact that "high economic activity in the industrial production area can lead to ecologic catastrophe, decrease of reproduction of labor power quality, resources deterioration." [7] Thus, we see the necessity to scientifically explain and maintain the balance of all types of economic activity within the region and municipal districts aiming to avoid a unidirectional growth of one or several types of economic activity against others. Thus, the area of economic activity supposedly has a complex structure created by sequentially interacting areas: technological, institutional, informational, industrial, consumer, etc.

Economic activity can be assessed at the level of an individual, households, social groups (institutions), municipal bodies, as well as at the level of a region and state. This research work touches upon the regional level of economic activity. In the authors' view, enterprises and institutions are the key source of economic activity in the region. Deterioration of conditions for their productive activity can lead to hard consequences for municipal districts due to decrease of the economic activity level at regional enterprises may become a threat for the whole local community's living 
conditions. That is the reason why the most popular approach to managing the region's economic activity is through capitalization, i.e. cost increase of the assets allocated on the territory of municipal entities as the regional economic instrument of influence on economic contacts at the macro regional, national and global levels [7]. Respectively, the evaluation of economic activity in the present study was conducted according to the results of economic activity of businesses and organizations with a status of legal identity and located within the municipal entities. Talking about other sources of economic activity in the region (households, small businesses, shadow economy), they were not studied primarily because of the lack of available statistical data.

Scientific novelty of the obtained study results includes an attempt to use - based on the evolutionary and genetic, as well as geographic and information approaches - a new system of economic activity (EA) indicators in municipal entities taking into account six types of economic activity: labor, production, environmental management, institutional, organizational and information. Respectively, each type of economic activity was preliminarily described with quantity indicators considering its factor specifics and original statistical data characterizing the peculiarities of social and economic development of municipal entities and city districts of Volgograd region [8], [9], [10], [11].

Dynamics of economic activity indicators of municipal entities within the regional economic space proves the processes of its concentration able to lead to creation of economic security threats towards municipal development due to the fact that not only a drop of economic activity leads to decrease of the level of municipal development economic security, but also a growth of its inter-municipal disproportions. A high spatial inconstancy and inequality of economic activity within municipal entities are able to negatively influence the stabilization of inter-municipal economic contacts providing sustainable development of the regional social and economic system.

The suggested methodological approach to describing the model of municipal economic activity has allowed to form a new system of relative indexes and indicators characterizing the conditions, resources and factors of economic activity in municipal entities (Table 1).

TABLE I. MODEL OF FACTOR STRUCTURE, ORIGINAL AND RELATIVE INDEXES OF ECONOMIC ACTIVITY (EA) IN MUNICIPAL ENTITIES

\begin{tabular}{|c|c|}
\hline $\begin{array}{c}\text { Economic } \\
\text { Activity (EA) }\end{array}$ & Relative Indexes (EA) \\
\hline $\begin{array}{l}\text { Labor Activity } \\
\text { EA }_{\mathrm{A}}\end{array}$ & $\begin{array}{l}\text { Labor capacity of organizations, number of } \\
\text { employees for one enterprise. }\end{array}$ \\
\hline $\begin{array}{l}\text { Production } \\
\text { Activity } \\
\text { EA }_{\mathrm{T}}\end{array}$ & $\begin{array}{l}\text { - Volume of manufactured products, ths. RUR per } \\
\text { organization. } \\
\text { - Volume of fixed investment, ths. RUR per } \\
\text { organization. }\end{array}$ \\
\hline $\begin{array}{l}\text { Natural } \\
\text { Management } \\
\text { Activity } \\
\text { EA }_{M}\end{array}$ & $\begin{array}{l}\text { - Volume of polluting emissions into the atmosphere, } \\
\text { tons per organization. } \\
\text { - Volume of water withdrawal from natural reservoirs, } \\
\text { ths. } \mathrm{m}^{3} \text { per organization. } \\
\text { - Cultivated areas of main agricultural crops on farms } \\
\text { of all categories, ths. ha per organization. }\end{array}$ \\
\hline $\begin{array}{l}\text { Institutional } \\
\text { Activity } \\
\text { EA INS }^{\text {Ins }}\end{array}$ & $\begin{array}{l}\text { - Amount of loan debts of organizations, ths. RUR per } \\
\text { organization. } \\
\text { - Accounts receivable of organizations, ths. RUR per } \\
\text { organization. }\end{array}$ \\
\hline
\end{tabular}

\begin{tabular}{|c|c|}
\hline $\begin{array}{c}\text { Economic } \\
\text { Activity (EA) }\end{array}$ & Relative Indexes (EA) \\
\hline $\begin{array}{l}\text { Organizational } \\
\text { Activity } \\
\text { EA }_{O}\end{array}$ & $\begin{array}{l}\text { - Relative share of prosperous enterprises, interests. } \\
\text { - Private revenues of municipal entities, mln. RUR per } \\
\text { organization in management sphere. }\end{array}$ \\
\hline $\begin{array}{l}\text { Informational } \\
\text { Activity } \\
\text { EA }_{\text {INF }}\end{array}$ & $\begin{array}{l}\text { - Amount of expenditures on ICT, ths. RUR per } \\
\text { organization. } \\
\text { - Number of employees using ICT per one } \\
\text { organization with ICT base, people. }\end{array}$ \\
\hline
\end{tabular}

Spatial analysis of multidimensionality of economic activity states in municipal districts forms the methodological ground of the current study. The suggested GIS-based spatial approach to the evaluation of economic activity in municipal districts of Volgograd region enables to visualize the state of economic activity of organizations at the municipal level and objectively assess its level for each of its components (labor, production, natural management, etc.) (Pic. 1) [12].

To correlate the six components of economic activity measured in various ranges and scales, six relative nonmetric indexes - aggregated $\mathrm{K}_{\mathrm{i}}$ indexes reflecting the approach degree of the respective type of economic activity $\mathrm{Q}_{\mathrm{i}}$ to the maximum $\mathrm{Q}^{\max }$ and minimum $\mathrm{Q}^{\mathrm{min}}$ indexes - were calculated. Relative positive indexes of institutional activity were described with the normalizing function (2).

$$
\begin{aligned}
& K_{i}=\left(Q^{i}-Q^{\min }\right) /\left(Q^{\max }-Q^{\min }\right) \\
& K_{i}=\left(Q^{\max }-Q^{i}\right) /\left(Q^{\max }-Q^{\min }\right)
\end{aligned}
$$

In the process of further spatial GIS-based analysis the figures of normalized values of different types of economic activity indexes throughout all municipal districts were equally divided using the classification method of 'equal intervals' into five classes in the values range of 0 to 1 with an interval of 0.2 . This allowed to provide effective correlation of the classification results displayed on the GIS themed digital maps.

On their basis, the integral index of economic activity $\left(\mathrm{K}_{\mathrm{EA}}\right)$ in municipal districts as an average of all aggregated indexes of the economic activity components $\left(\mathrm{K}_{\mathrm{i}}\right)$ was calculated.

To evaluate the spatial diversity of economic activity in municipal entities a set of statistical characteristics (average value $\mathrm{x}_{\mathrm{cp}}$, standard deviation $\sigma$, asymmetry coefficient As, excess coefficient Ex, variation coefficient $v$ ) characterizing the peculiarities of their geographic variation was used. [13]

\section{RESULTS AND DISCUSSION}

As a result of the conducted calculation of statistical characteristics for the six economic activity components there was discovered their essential spatial variability $(v>0,33)$ in 2016 proving existence of the factors that dramatically differentiate the state of economic activity of municipal districts in Volgograd region (Table 2). 
TABLE II. MODEL OF FACTOR STRUCTURE, INITIAL AND RELATIVE INDEXES OF ECONOMIC ACTIVITY (EA) IN MUNICIPAL ENTITIES

\begin{tabular}{|c|c|c|c|c|c|}
\hline Index $\mathbf{K}_{\mathbf{i}}$ & $\mathbf{x}_{\mathbf{c p}}$ & $\boldsymbol{\sigma}$ & $\mathbf{A s}$ & $\mathbf{E x}$ & $\mathbf{v}$ \\
\hline $\mathrm{K}_{\mathrm{A}}$ & 0.38 & 0.25 & 0.54 & 2.39 & 0.66 \\
\hline $\mathrm{K}_{\mathrm{T}}$ & 0.11 & 0.2 & 3.02 & 13.43 & 1.82 \\
\hline $\mathrm{K}_{\mathrm{M}}$ & 0.38 & 0.3 & 0.74 & 2.37 & 0.79 \\
\hline $\mathrm{K}_{\mathrm{INS}}$ & 0.79 & 0.29 & -1.58 & 4.18 & 0.37 \\
\hline $\mathrm{K}_{\mathrm{O}}$ & 0.39 & 0.21 & 0.34 & 3.44 & 0.54 \\
\hline $\mathrm{K}_{\mathrm{INF}}$ & 0.24 & 0.23 & 1.81 & 5.95 & 0.96 \\
\hline $\mathrm{K}_{\mathrm{EA}}$ & 0.35 & 0.22 & 0.67 & 3.59 & 0.63 \\
\hline
\end{tabular}

The themed digital maps created in GIS visualize the spatial pattern of the six economic activity types on the territory of municipal entities in Volgograd region in 2016 (excluding the cities of Volgograd, Volzhsky and Kamyshin).

The aggregated index of labor activity $\mathrm{K}_{\mathrm{A}}$ reflects the level of involvement of the economically active population into production processes by businesses and organizations in municipal districts; thus, the higher index values mean the higher level of labor activity (Fig. 1). The labor activity conditions in municipal districts of Volgograd region are characterized by cardinal spatial variability of its index value at the level higher than average throughout the region $(v=$ 0,66 ; As $=0,54 ; \mathrm{Ex}=2,39$ ), with obvious areas of relatively high labor activity in Kotelnikovsky, Pallasovsky, Kamyshinsky, Kotovsky, Yelansky, Mikhailovsky and Frolovsky municipal districts that have managed to reach the highest employment indexes per organization (15-22 people) in the region in 2016 (Table 2).

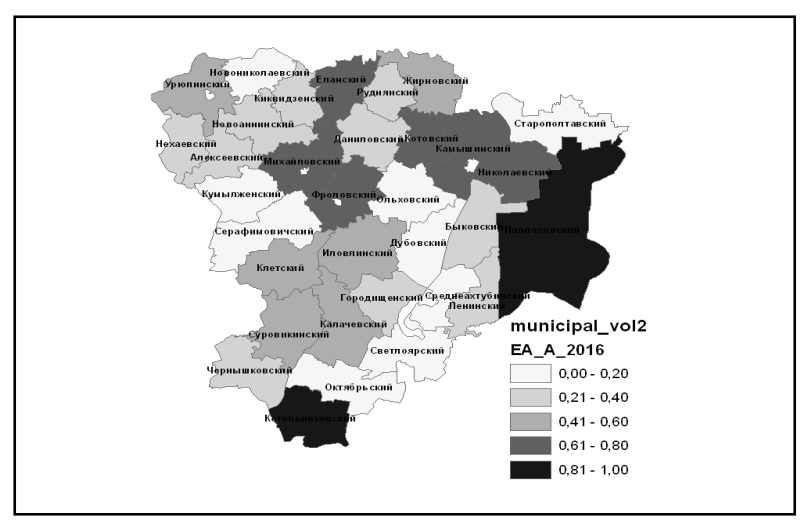

Fig. 1. Index of labor activity $\left(\mathrm{K}_{\mathrm{A}}\right)$ in municipal districts of Volgograd region in 2016

Production activity of organizations $\left(\mathrm{EA}_{\mathrm{T}}\right)$ is characterized by production and fixed investment amounts per organization. The state of production activity on the territory of Volgograd region in 2016 was characterized by significant spatial variability at the level significantly lower than average throughout the region $(v=1,82 ; \mathrm{As}=3,02 ; \mathrm{Ex}=13,43)$, with localization of high industrial production and fixed investment volumes only in Kotelnikovsky district. The values of these indexes are several times higher than similar indexes for other municipal districts of Volgograd region. The separate group of higher production activity includes Ilovlinsky, Kotovsky,
Zhirnovsky, Yelansky, Mikhailovsky and Gorodishchensky municipal districts. (Fig. 2)

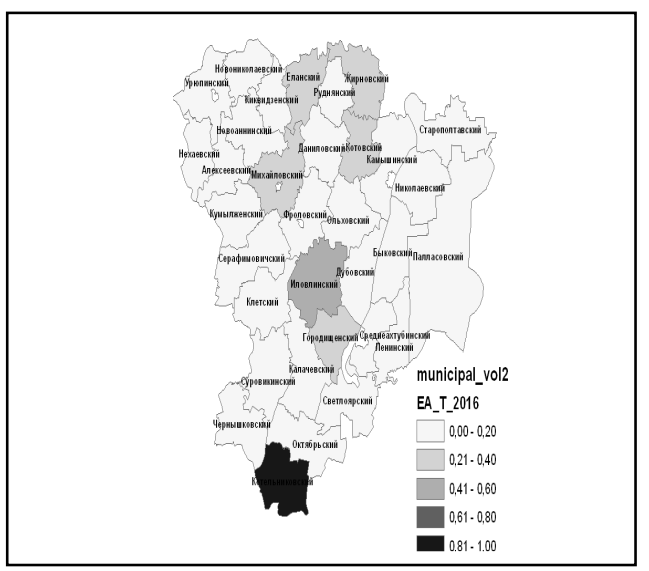

Fig. 2. Index of production activity $\left(\mathrm{K}_{\mathrm{T}}\right)$ in municipal districts of Volgograd region in 2016.

Natural management activity of organizations $\left(\mathrm{EA}_{\mathrm{M}}\right)$ is characterized by the volume of polluting substances emissions into the environment, the volume of water consumption from natural reservoirs, the cultivated areas for growing agricultural crops in economic entities of all categories per organization. The state of natural management activity in Volgograd region in 2016 was characterized by significant spatial variability at the level lower than average throughout the region $(v=0,79$; As $=0,74 ; E x=2,37$ ), with localization of high values of the natural management index in Olkhovsky, Frolovsky, Svetloyarsky and Nikolaevsky municipal districts. (Fig. 3)

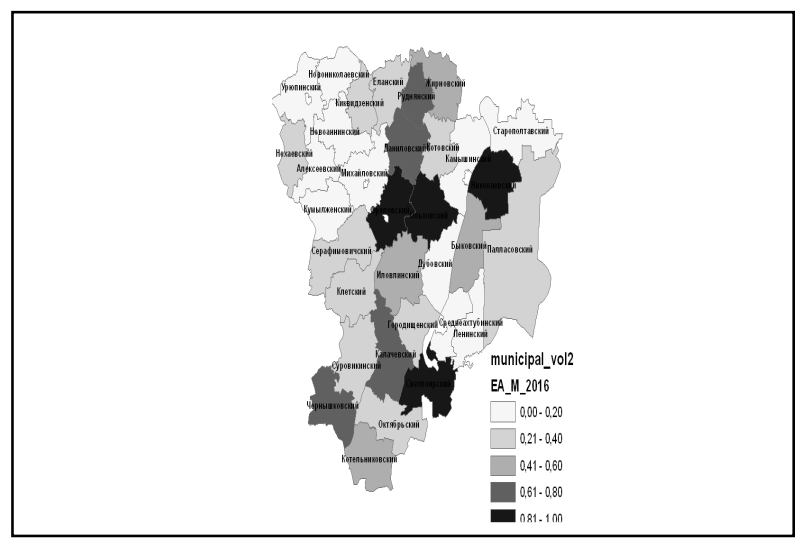

Fig. 3. Index of natural management activity $\left(K_{M}\right)$ in municipal districts of Volgograd region in 2016.

Institutional activity of organizations $\left(\mathrm{EA}_{\mathrm{INS}}\right)$ is characterized not only by the existence, but also the fruitful functioning of the whole group of interrelated institutions (formal laws and informal relations) supporting the mechanism of development for the whole system of sustainable development in municipal entities. Institutional activity is characterized by the legal discipline and business duty performance of organizations (EA $\left.\mathrm{INS}_{\mathrm{IN}}\right)$. The area of institutional activity in Volgograd region in 2016 was characterized by significant spatial variability at the level much higher than average throughout the region $(v=$ 0,37; As $=-1,58 ; \mathrm{Ex}=4,18)$, i.e. it was predominantly positive throughout the region. The greatest level of loan debts and accounts receivable of organizations in 2016 was reported 
in Kotelnikovsky, Gorodishchensky, Frolovsky and Mikhailovsky municipal districts (Fig. 4).

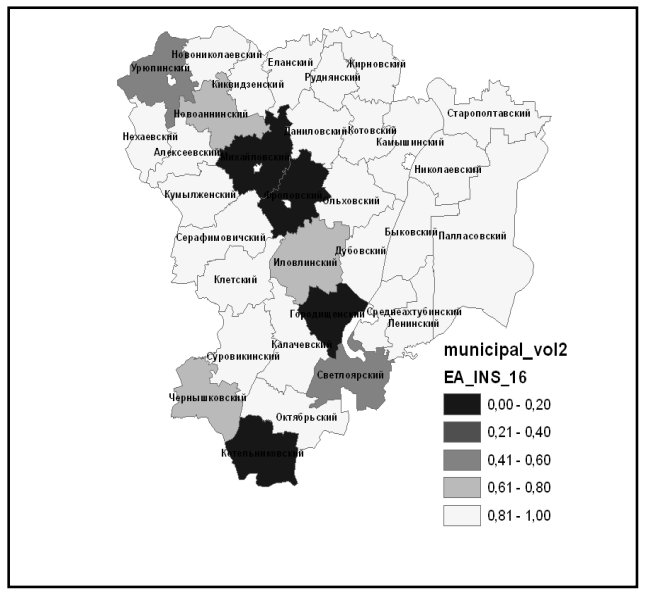

Fig. 4. Index of institutional activity $\left(K_{\mathrm{INS}}\right)$ in municipal districts of Volgograd region in 2016.

Organizational activity $\left(\mathrm{EA}_{\mathrm{O}}\right)$ is characterized by the level of interaction coordination talking about the bodies of state management, enterprises, regional organizations and the effectiveness of their financial and economic activity $\left(\mathrm{EA}_{\mathrm{O}}\right)$. The area of organizational activity in Volgograd region in 2016 was characterized by significant spatial variability at the level lower than average throughout the region $(v=0,54$; As $=$ 0,34; $\mathrm{Ex}=3,44)$. The worst situation in the business activity revenue of organizations and the amount of their own earnings to municipal budgets in 2016 was reported within the group of neighboring districts: Kumylzhensky, Serafimovichsky, Frolovsky, Olkhovsky, Ilovlinsky, Dubovsky and Bykovsky (Fig. 5).

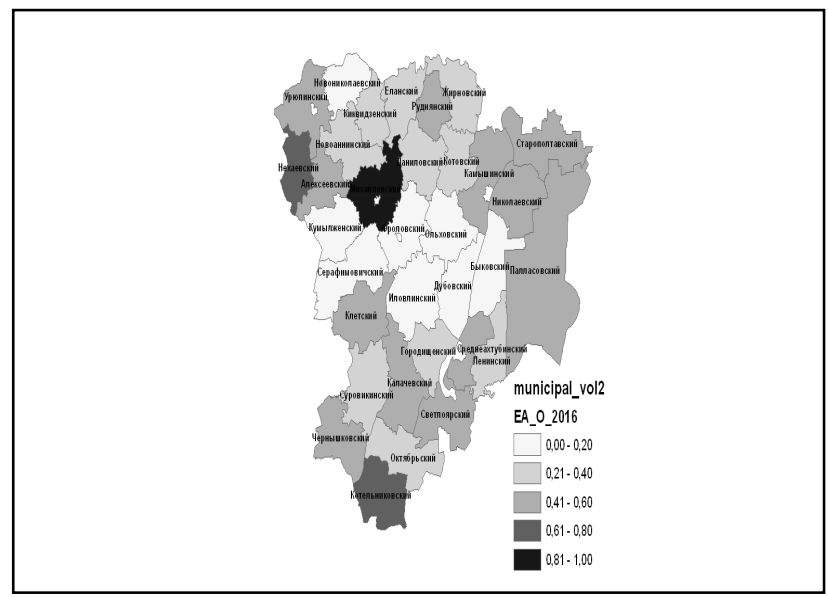

Fig. 5. Index of organizational activity $\left(\mathrm{K}_{\mathrm{O}}\right)$ in municipal districts of Volgograd region in 2016.

Finally, informational activity $\left(\mathrm{EA}_{\mathrm{INF}}\right)$ is characterized by involvement of businesses and organizations in municipal districts into the regional informational space, which provides the effectiveness of inner and cross-municipal economic contacts. The area of informational activity of organizations in Volgograd region in 2016 was characterized by significant spatial variability at the level lower than average throughout the region $(v=0,96 ;$ As $=1,81 ; \operatorname{Ex}=5,95)$. The most advantageous situation with the volume of investments into ICT development and the number of active ICT users inside organizations with the ICT base was reported in Kotelnikovsky, Mikhailovsky, Zhirnovsky, Kotovsky and Kamyshinsky municipal districts. (Fig. 6)

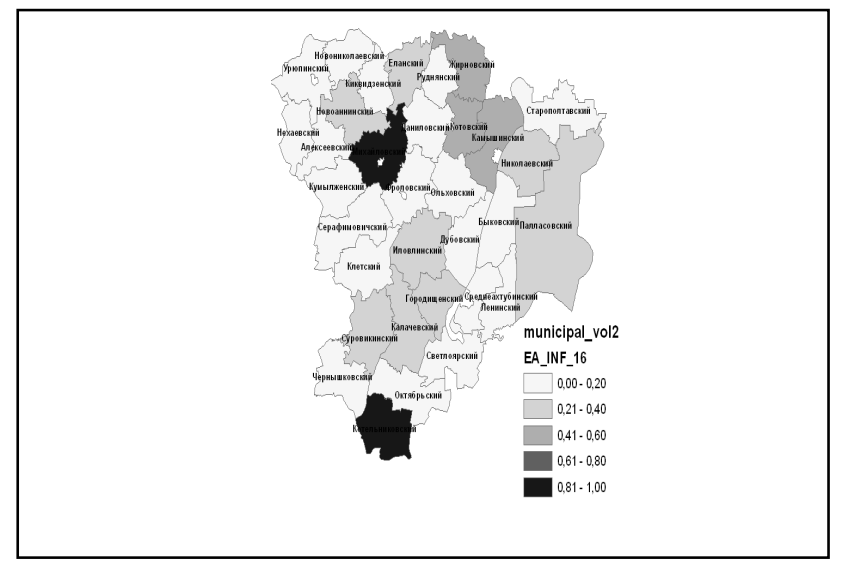

Fig. 6. Index of informational activity $\left(\mathrm{K}_{\mathrm{INF}}\right)$ in municipal districts of Volgograd region in 2016.

Assessment of the integral index of economic activity $\left(\mathrm{K}_{\mathrm{EA}}\right)$ in municipal districts of Volgograd region in 2016 was conducted taking into account the evaluation results for the six economic activity components (Fig. 7). The state of economic activity for that year can be characterized as significantly variable at the level lower than average throughout the region $(v=0,63 ;$ As $=0,67 ; \mathrm{Ex}=3,59)$, with three spatially determined areas in reference to the high level of economic activity in the west of the region (Mikhailovsky municipal district), in Zavolzhie (Nikolaevsky municipal district), and in the south of the region (Kalachyovsky and Kotelnikovsky municipal districts).

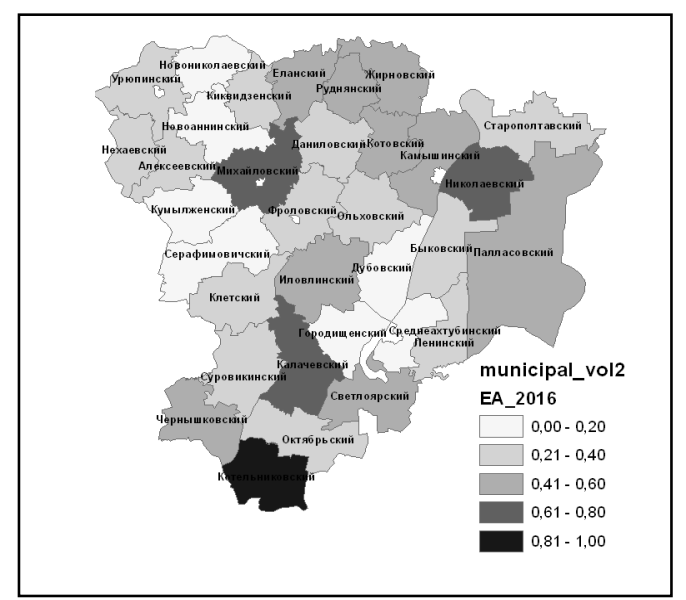

Fig. 7. Integral index of economic activity $\left(\kappa_{\mathrm{EA}}\right)$ in municipal districts of Volgograd region in 2016.

\section{CONCLUSION}

Spatial inequality of economic activity in municipal entities is a natural property of the regional social and economic system. However, it is extremely important for this inequality not to become the factor of economic stagnation and strong depressive state of the municipal entities with lower economic activity caused by decline in population, 
migration of labor force and business activity to more developed municipal and city districts. The period of creation of regional centers for economic attraction and growth accompanied by the spatial concentration of economic activity needs to be replaced with the stage of managed alignment of the level of social and economic development of municipal entities.

Execution of both the evolutionary and genetic and spatial approaches to analysis and evaluation of the economic activity conditions in municipal entities based on the geographic informational technologies in terms of the complex information and analytical system of economic activity management in the region is able to increase the quality and effectiveness of the decisions made in the area of strategic management of regional and municipal social and economic development.

\section{Acknowledgement}

We express our gratitude to the Russian Humanitarian Scientific Foundation and the Administration of Volgograd region for their financial support in execution of the present research (Grant No.17-12-34047 a/B).

\section{References}

[1] E.A. Orekhova, A.V. Plyakin, and V.A. Ekova, "Evolutionary and genetic approach to formation of the system of sustainable development indicators for municipal entities," [Evolyutsionno-geneticheskii podkhod $\mathrm{k}$ formirovaniyu sistemy indikatorov ustoichivogo razvitiya munitsipal'nykh obrazovanii], Belgorod State University Scientific Bulletin. History. Politology. Economics. Computer Science, Vol. 22/1, pp. 76-81, No.1 (120) 2012. [Nauchnye vedomosti Belgorodskogo gosudarstvennogo universiteta. Ser.: Istoriya. Politologiya. Ekonomika. Informatika. Vyp. 22/1]

[2] D.N. Shaikin, "Measurement of economic activity of population as an indicator determining labor potential development in the region (by the example of Omsk region)" [Izmerenie ekonomicheskoi aktivnosti naseleniya kak indikatora, opredelyayushchego razvitie trudovogo potentsiala regiona (na primere Omkoi oblasti)], Economics and Management. No.14(53), pp. 102-105, 2007. [Ekonomika i upravlenie].

[3] N.V. Rotmanova, "Structure of economic activity," [Struktura ekonomicheskoi aktivnosti], International Journal of Experimental Education [Mezhdunarodnyi zhurnal eksperimental'nogo obrazovaniya], No. 6, pp. 30-31, 2009.

[4] V.Yu. Mamaeva, "Labor activity as a social and economic category," [Trudovaya aktivnost' kak sotsial'no-ekonomicheskaya kategoriya], Herald of Omsk University, Series "Economics," [Vestnik Omskogo universiteta. Seriya Ekonomika], No. 4, pp. 60-68, 2004.

[5] I.V. Vasilenko, E.N. Vasilieva, "Formation of economic activity: theoretical research schemes," [Formirovanie ekonomicheskoi aktivnosti: teoreticheskie skhemy issledovaniya], Science Journal of VolSU, Series 7, Philosophy [Vestnik Volgogradskogo gosudarstvennogo universiteta. Seriya 7, Filosofiya], No.3(29), pp. 115$121,2015$.

[6] A.V. Plyakin, "Evolutionary and genetic approach to measuring and assessing economic activity space of southern macro region," [Evolyutsionno-geneticheskii podkhod $\mathrm{k}$ izmereniyu $\mathrm{i}$ otsenke prostranstva ekonomicheskoi aktivnosti v yuzhnom makroregione], Economics of Regional Development: Problems, Quest, Solutions [Ekonomika razvitiya regiona: problemy, poiski, resheniya], No.9, pp. 321-334, 2008.
[7] E.I. Styazhkina, I.I. Styazhkin, "Management limits of economic activity in the region," [Granitsy upravleniya ekonomicheskoi aktivnost'yu v regione], Bulletin of the Technological University [Vestnik Kazanskogo tekhnologicheskogo universiteta], No.24, pp. 164-169, 2011.

[8] "City Districts and Municipal Entities of Volgograd Region - 2016: Statistical Overview [Gorodskie okruga i munitsipal'nye raiony Volgogradskoi oblasti 2016: stat. obozr.]." Territorial body of the Federal State Statistics Service in Volgograd region [Terr. organ Fed. sluzhby gos. statistiki po Volgograd. obl.]. Volgogradstat, Volgograd, 2017.

[9] "Indicators of Informational Society in Volgograd Region in 2016: Statistical Overview [Indikatory informatsionnogo obshchestva Volgogradskoi oblasti v 2016 godu: stat. obzor]." Territorial body of the Federal State Statistics Service in Volgograd region [Terr. organ Fed. sluzhby gos. statistiki po Volgograd. obl.]. Volgogradstat, Volgograd, 2017.

[10] "Natural Environment of Volgograd Region. 2016: Statistical Overview [Okruzhayushchaya prirodnaya sreda Volgogradskoi oblasti. 2016 :stat. obozrenie]."Territorial body of the Federal State Statistics Service in Volgograd region [Terr. organ Fed. sluzhby gos. statistiki po Volgograd. obl.]. Volgogradstat, Volgograd, 2017.

[11] "Labor and Employment in Volgograd Region: Statistical Overview [Trud i zanyatost' v Volgogradskoi oblasti: Statisticheskoe obozrenie]." Territorial body of the Federal State Statistics Service in Volgograd region [Terr. organ Fed. sluzhby gos. statistiki po Volgograd. obl.]. Volgogradstat, Volgograd, 2017.

[12] "Statement of ArcGIS 10.1" [Web Source] / ArcGIS Resources. URL: http://resources.arcgis.com/ru/help/main/10.1/index.html\#/na/00qn0000 001p000000/ (Date of reference: 30.12.2017)

[13] "Instruments of financial and investment analysis. Statistical parameters [Instrumenty finansovogo i investitsionnogo analiza. Statisticheskie parametry]." [Web Source] / Investment-analysis.ru [Webpage]. URL: http://investment-analysis.ru/metodFC2/daily-variance-arithmetic-meandeviation.html (Date of reference: 30.11.2017). Printscreen. 